Karstenia 53: 49-54, 2013

\title{
Environments influence the psychrophily of fungi and oomycetes in the cryosphere.
}

\author{
TAMOTSU HOSHINO and NAOYUKI MATSUMOTO
}

\begin{abstract}
HOSHINO, T., \& MATSUMOTO N. 2013: Environments influence the psychrophily of fungi and oomycetes in the cryosphere.- Karstenia 53: 00-00. HELSINKI. ISSN 0453-3402
\end{abstract}

Cryophilic fungi are defined by the physiological characteristics of their different life stages. Abiotic and biotic environmental factors influence physiological characteristics of cryophilic fungi and oomycetes. The relationships between fungal psychrophily and their habitat is discussed.

Key words: cryosphere, psychrophile, psychrophily, life cycle, Sclerotinia nivalis, snow moulds, Typhula

Tamotsu Hoshino, Biomass Refinery Research Center (BRRC), National Institute of Advanced Industrial Science and Technology (AIST), 739-0046 Higashi-hiroshima, Japan; e-mail: tamotsu.hoshino@aist.go.jp

Naoyuki Matsumoto, Graduate School of Agriculture, Hokkaido University, Sapporo 060-8589,Japan; e-mail: nowmat@a011.broada.jp

\section{What are cryophilic fungi ?}

Fungi normally have different cells in their life cycle and fungal thermal dependence varies according to their life cycle stages and is thus completely different from that of bacteria. Various examples show that the concept of psychrophily in bacteria by Morita (1975) does not apply to fungi. Hence, we proposed the term "cryophilic fungi" to denote the organisms adapted to the cryosphere (Hoshino \& Matsumoto 2012). Cryophilic fungi include not only saprophytes but also parasites, as well as symbionts (Hoshino et al. 2013a). Some groups of cryophilic organisms attack overwintering plants and other living organisms including fungi on/in/under snow. In this review, we discuss the diversity and ecophysiological characteristics of these fungi. The concept of cryophilic fungi is defined as fungi that are present in the cryosphere, complete their lifecycles (sexual and/or asexual reproductions), and grow under subzero temperature where wa- ter remains in the solid state such as snow and ice. The concept of cryophilic fungi also applies to unculturable fungi such as mycorrhizal fungi.

\section{Research history}

Fungi in the cryosphere have been less studied than those in temperate conditions. However, these organisms and their activities were recorded two centuries ago. The first observation was probably from rotted winter barley under snow cover in Toyama, Japan in 1788 (Hori 1934). Eriksson (1879) published a scientific report on winter injury of winter crops in Sweden. Rostrup (1888) was the first to publish an overview of the fungi of Greenland. In his review, he listed phytopathogenic fungi from Flora Danica (Hornemann 1836). Fischer (1888) was probably the first to report that an unidentified fungus grew at $0^{\circ} \mathrm{C}$. Fungi in Antarctica have been surveyed since the beginning of the $20^{\text {th }}$ century 
(e.g. Bommer \& Rousseau 1900). Cooke (1944) reported mushrooms in melted snowbanks in the alpine region of North America. Berry \& Magoon (1934) and Morita (1966) summarized early studies of microorganisms, including fungi that grew at low temperatures.

\section{Diversity}

Snow fungi associate with snow algae in cryoseston which is defined as the community of organisms living on the snow (Nedbalová et al. 2008). Kol (1968) listed 82 species of snow fungi and fungi incertae sedis: Chionaster nivalis (Bohlin) Wille, C. bicornis Kol, and ascomycetous Selenotila nivalis Lagerh are among typical snow fungi.

The term snow moulds refers to pathogenic fungi under snow. They attack dormant plants such as forage crops, winter cereals, and conifer seedlings at low temperatures under snow cover (e.g. Smith 1989, Hsiang et al. 1999, Hoshino et al. 2009). Snow cover maintains darkness, humidity, and low temperatures and protects plants from cold and desiccation (Matsumoto \& Hoshino 2008). "Snow moulds" or "snow mould fungi" is a generic name including diverse taxonomic groups of pathogenic organisms. Bruehl et al. (1966) found 55 taxa including unidentified species from winter wheat in early spring, and Årsvoll (1975) described 33 taxa from forage grasses just after snowmelt. However, most of these organisms are considered not pathogenic, or simply remained inactive under snow.

Matsumoto isolated 47 taxa from sclerotia of T. incarnata Lasch, and T. ishikariensis S. Imai, (Matsumoto 1989). Among these isolates a traditional zygomycete Mucor hiemalis Wehmer was found. Ascomycetes found included Clonostachys rosea f. rosea (Link) Schroers, Samuels, Seifert \& W. Gams (syn. Gliocladium roseum), Hormonema sp., Lecanicillium lecanii (Zimm.) Zare \& W. Gams (syn. Verticillium lecanii), Paraconiothyrium minitans (W.A. Campb.) Verkley (syn. Coniothyrium minitans), Trichoderma harzianum Rifai, Trichoderma pseudokoningii Rifai. All these had parasitic activities to sclerotia of Typhula spp. Basidiomycete $\mathrm{Cyl}$ indrobasidium parasiticum D.A. Reid is a mycoparasite of sclerotia of T. incarnata in Scotland (Woodbridge et al. 1989), and ascomycetes
Episclerotium sclerotioum (Rostr.) L.M. Kohn, and Episclerotium sclerotipus (Boud.) L.M. Kohn are also parasites of sclerotia of Typhula phacorrhiza (Reuchard) Fr. and Sclerotinia spp (Kohn \& Nagasawa 1984).

Snowbank fungi are mushrooms emerging after snowmelt. Snowbanks linger till spring and summer in heavily timbered areas of the high Rocky Mountains. The snow bank fungi are comprised of ecologically diverse groups that belong to both Ascomycetes and Basidiomycetes. They are adapted to the unique microclimate provided by remnant snow in high elevation conifer forests (Cripps 2009). This set of fungi was subsequently called the "Snowbank flora" by Smith (1975). Moser (2004) described the snowbank "fungi" unique to North America. Subsequently, Cha et al. (2010) found snowbank fungi also in Hokkaido, northern Japan.

\section{Effect of abiotic factors on thermal dependence}

Most studies on the relationship between microorganisms and temperature have focused on physiological characteristics for its own sake and did not consider biological interactions, despite the fact that fungi in nature interact with various organisms in different environments. Wolf \& Wolf (1949) stated that conceivably, the temperature differential might be an important factor when two or more species were competing for substrata but that it may not necessarily constitute the controlling factor.

In Norway, the basidiomycetous snow mould fungus, Typhula ishikariensis was divided into three groups (I, II and III) based on their mating reaction (Matsumoto \& Tronsmo 1995, Matsumoto et al. 1996). T. ishikariensis group III is prevalent in the northernmost part of Norway (Matsumoto \& Tronsmo 1995, Matsumoto et al. 1996), Greenland (Hoshino et al. 2006), and Svalbard (Hoshino et al. 2003). The distribution pattern of this fungus indicates that group III is more adapted to low temperatures than groups I and II. Isolates of groups I and II grow normally at $10^{\circ} \mathrm{C}$ on PDA, whereas group III isolates show irregular growth at this temperature (Matsumoto et al. 1996, Hoshino et al. 1997), and hyphal growth stops at $15^{\circ} \mathrm{C}$. However, mycelia of group III isolates showed normal growth 
at $10^{\circ} \mathrm{C}$ when PDA cultures were covered with water (Hoshino et al. 2008).

The ascomycetous snow mould, Sclerotinia borealis Bubák \& Vleugel prevails where soil freezing is severe (Tomiyama 1955, Röed 1960, Nissinen 1996). Tomiyama (1955) cultured $S$. borealis and Typhula incarnata on both frozen and unfrozen potato dextrose agar (PDA) plates that were kept outside in Sapporo, northern Japan. Mycelial growth of T. incarnata was inhibited on frozen plates, but $S$. borealis grew faster on frozen plates than on unfrozen ones. His experiments were not made under controlled conditions and have not been reproduced by others. Under controlled conditions, we confirmed his results that $S$. borealis grew on frozen PDA (Hoshino et al. 2009, 2010). S. borealis showed normal mycelial growth under the frozen condition, and mycelial growth rate on frozen plates at $-1^{\circ} \mathrm{C}$ was faster than that on unfrozen PDA at its optimal growth temperature of $4-10^{\circ} \mathrm{C}$. S. borealis can grow at low water potential on plates containing twice the concentration of medium ingredients (Tomiyama 1955), sucrose and $\mathrm{KCl}$ (Bruehl \& Cunfer 1971) as well as D-mannitol (Namikawa et al. 2004). An increase in intracellular osmosis enhanced mycelial growth and shifted the optimal mycelial growth temperature from $10-15^{\circ} \mathrm{C}$ to $4^{\circ} \mathrm{C}$. However, mycelial growth of other snow moulds such as Sclerotinia nivalis I. Saito and Sclerotinia trifoliorum Erikss was inhibited at low water potential (Hoshino et al. 2009, 2010). Therefore, osmophilism of $S$. borealis was probably a unique feature to adapt to severe freezing. These results suggested that the cardinal temperature range of cryophilic fungi varies with cultural conditions.

\section{Effect of biotic factors on thermal dependence}

Mycelial growth of $T$. ishikariensis group I on PDA at $0^{\circ} \mathrm{C}$ was half that of its optimal growth at $10^{\circ} \mathrm{C}$. However, when cultures were covered with unsterile soil to introduce natural microbial antagonists, mycelial growth was much less at $10^{\circ} \mathrm{C}$ than at $0^{\circ} \mathrm{C}$ (Matsumoto \& Tajimi 1988, Hsiang et al. 1999). These facts indicate that $T$. ishikariensis group I is unable to develop mycelia at $10^{\circ} \mathrm{C}$ in nature
The ascomycetous snow mould, Sclerotinia nivalis is psychrotolerant and its optimal mycelial growth temperature is $20^{\circ} \mathrm{C}$ (Saito 1997). However, the fungus could infect santonica $(A r-$ temisia cina) and carrot at 0 or $3{ }^{\circ} \mathrm{C}$ but not at $15^{\circ} \mathrm{C}$ (Saito 2001). Sclerotia germinated rapidly on unsterilised soil at $0^{\circ} \mathrm{C}$, producing abundant mycelia to invade carrot roots. In contrast, at $20^{\circ} \mathrm{C}$, myceliogenic germination failed to occur, and consequently carrot roots escaped from infection. Germination of sclerotia and mycelial growth were probably affected by suppressive activities of soil microorganisms (Saito 2001). This fungus may be considered as "psychrophile" (Morita 1975) from its ecological view point. These facts suggest that environmental factors are one of the important factors, determining cardinal temperature range of cryophilic fungi. Fig. 1 illustrates the concept of cryophilic fungi and the relationship with fungal psychrophily and environmental factors.

\section{Ecophysiology of eurythermal cryophilic fungi}

Snow moulds are unique in that they prevail when their hosts lie dormant during the winter. However, not all of them prevail exclusively under snow. Matsumoto (1994) divided them into obligate and facultative snow moulds. Facultative snow moulds are relatively fastgrowing and occur under moist environmental conditions when plants are not necessarily covered with snow or even in summer; e.g. Sclerotinia trifoliorum encourages clover rot in damp winter (Lester \& Large 1958), and Microdochium nivale (Fr.) Samuels \& I.C. Hallett causes leaf blotch of wheat in summer (Asuyama 1940).

Mesophilic ascomycetes Gremmeniella abietina var. abietina (Lagerb.) M. Morelet and Gremmeniella abietina var. balsamea Petrini, L.E. Petrini, Lafl. \& Ouell. cause scleroderris canker of conifers (Lijia et al. 2010). Plants with diseased needles are often found below the snowline, and winter temperatures influence infection rate; those overwintering at -7 and $-3^{\circ} \mathrm{C}$ were more seriously diseased than those kept at $0^{\circ} \mathrm{C}$ (Petäistö \& Laine 1999). These fungi can grow at subzero temperatures (Yokota et al. 1974). These findings suggest that $G$. abietina is active in a 


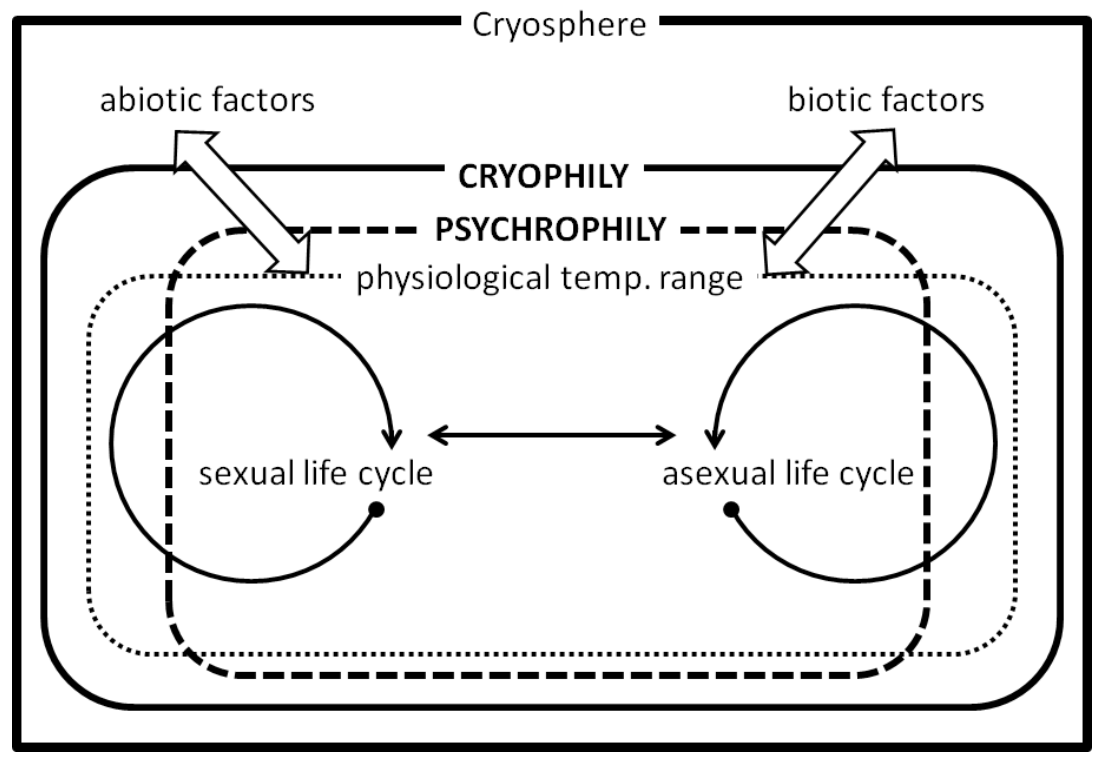

Figure 1. The concept of cryophilic fungi and its relationship with psychrophily and environmental factors. wide temperature range between subzero to summer air temperatures in the cryosphere. A similar life cycle occurs in the ascomycetes among Microsphaeropsis sp., causing canker on Cornus controversa (Akimoto1992).

\section{Evolution of cryophilic fungi}

Fungal fossil diversity increased throughout the Paleozoic Era with all modern classes reported in the Pennsylvanian Epoch (320-286 Ma) (Taylor et al. 1994). Present climatic zones on earth were formed from the Cretaceous period (145-66 $\mathrm{Ma})$, then plants adapted in cold environment (Sakai 1995). Cryophilic fungal saprophytes probably evolved from mesophilic saprophytes, and consequently some species of cryophilic fungi acquired pathogenicity against overwintering plants (Matsumoto 1997). Pythium, Sclerotinia and Typhula are typical genera of snow moulds, and species of mesophiles and psychrotolerants are greater in number than psychrophiles. Pathogenicity and cold-adaptation are essential factors for fungi to become cryophilic phytopathogens, and these factors co-evolved in Typhula (Hoshino 2005).

Pathogenicity is strongly correlated with freezing resistance in oomycetous snow moulds
(Hoshino et al. 2009, 2013b). Fungi in permafrost are characterized by both the presence of natural cryoprotectants such as plant substrates or derivatives in these ecotopes and the ability to utilize their inherent mechanisms of protection (Ozerskaya et al. 2009). Stakhov et al. (2008) demonstrated that ancient seeds of higher plants constituted a specific habitat for microorganisms in frozen ground, which favoured their survival for millennia. Cold-accumulated plants also store cryoprotectants in their cytosol, and Pythium spp. in infected tissues, probably utilize host cryoprotectants to tolerate freezing.

Snow moulds are invariably stress tolerant, but their level of tolerance differs from organism to organism. They are either airborne or soilbore, or both. Airborne pathogens are ruderal or $r$-selected, reaching new habitat through spores before snow cover, and different strains of the same species share plant tissues to develop. Though not airborne, Pythium spp. have the same strategy. Soilborne snow moulds, except Pythium spp., exploit plant tissues nearby and excludes other strains through intraspecific antagonism. $T$. ishikariensis is, in this context, a typical $K$-strategist among snow moulds (Matsumoto 1992). The mode of epidemiology does not coincide with cold-tolerance in snow moulds and divides them into two categories, i.e., facultative and obligate 
snow moulds (Matsumoto1994). S. borealis, T. incarnata and T. ishikariensis are obligate snow moulds that prevail exclusively under snow and are tolerant to cold with different mechanisms. Pythium spp. and Microdochium nivale are facultative snow moulds and can develop without snow, even in summer during cool and damp periods. They are moderately tolerant of cold. Though fungal pathogens are less frequently recorded from the cryosphere than from the temperate zone, their diversity in adaptation strategy is significant and needs further investigations to reveal the complex ecosystem of the cryosphere.

\section{Conclusions}

The concept of cryophilic fungi is defined as fungi that are present in the cryosphere, complete their lifecycles, and grow under subzero temperatures where water remains in the solid state such as snow and ice. Their psychrophily is defined by physiological characteristics at each stage of their lifecycle. Environmental features (abiotic and biotic factors) also influence the physiological characteristics of cryophilic fungi.

\section{Acknowledgements:}

This research was financially supported in part by Grant-in Aid for Scientific Research (KAKENHI) (no. 23247012) from the Japanese Society for the Promotion of Science (JSPS). Ernest Emmett is warmly thanked for checking the language.

\section{References}

Akimoto, M. 1992: A new canker disease of Cornus controversa caused by Microsphaeropsis sp. - Transactions of the Meeting in Hokkaido Branch of the Japanese Forest Society 40: 27-29. [in Japanese]

Asuyama, H. 1940: Leaf blotch of wheat caused by Fusarium nivale (Fr.) Ces. - Annals of Phytopathological Society of Japan 10: 51-54. [in Japanese]

Årsvoll, K. 1975: Fungi causing winter damage on cultivated grasses in Norway. - Meldinger Norges Landbrukshøgsk 54: 1-49.

Berry, J.A. \& Magoon, C.A. 1934: Growth of microorganisms at below $0^{\circ} \mathrm{C}$. - Phytopathology 24: 780-796.

Bommer, E. \& Rousseau, M. 1900: Note preliminaire sur les champignons recueillis par l'Expedition Antarctique Belge. - Bulletin de la Classe des sciences. Académie royale de Belgique 8: 540-546.

Bruehl, G.W. \& Cunfer, B.M. 1971: Physiologic and environmental factors that affect the severity of snow mould of wheat. - Phytopathology 61: 792-799.
Bruehl, G.W., Srague, R., Fischer, W.B., Nagamitsu, M., Nelson, W.L. \& Vogel, O.A. 1966: Snow mould of winter wheat in Washington. - Washington Agricultural Experimental Station Bulletin 677: 1-21.

Cha, J.Y., Lee, S.Y., Chun, K.W., Lee, S.Y. \& Ohga, S. 2010: A new record of a snowbank fungus, Mycena overholtsii, from Japan. - Journal of the Faculty of Agriculture, Kyushu University 55: 77-78.

Cooke, W.B. 1944: Notes on the ecology of the fungi of Mount Shasta. - American Midland Naturalist 31: 237-249.

Cripps, C. 2009: Snowbank fungi revised. - Fungi 2: 47-53.

Eriksson, J. 1879: En ny parasitsvamp å hvete, Typhula graminum Karst.: Med en litorafierad och delvis fäeglagd tafla - Kongl. Landtbr.-Akad. Handl. o. Tidskr. 3: $1-6$

Fischer, B. 1888: Bakterienwachsthum bei $0^{\circ} \mathrm{C}$, sowie über das Photographireren von Kulturen leuchtender Bakterien in ihren eigenen Lichte. - Centralblatt für Bakteriologie und Parasitenkunde 4: 89-92.

Hori, S. 1934: Old record of snow moulds of winter wheat. - Journal of Plant Protection (ByuchugaiZasshi) 21: 165-166. [in Japanese]

Hornemann, J.W. 1836: Flora Danica fascicle 37. Hauniae. Copenhagen. $60 \mathrm{pp}$.

Hoshino, T. 2005: Ecophysiology of snow mould fungi. Current Topic in Plant Biology 6: 27-36.

Hoshino, T., Tronsmo, A.M., Matsumoto, N., Ohgiya, S. \& Ishizaki, K. 1997: Effects of temperature on growth and intracellular proteins of Norwegian Typhula ishikariensis isolates. - Acta Agriculturæ Scandinavica, Section B - Soil \& Plant Science 47: 185-189.

Hoshino, T., Saito, I. \& Tronsmo, A.M. 2003: Two snow mould fungi from Svalbard. - Lidia 6: 30-32.

Hoshino, T., Saito, I., Yumoto, I. \& Tronsmo, A.M. 2006: New findings of snow mould fungi from Greenland. Meddelelser om Grønland, Bioscience 56: 89-94.

Hoshino, T., Tronsmo, A.M. \& Yumoto, I. 2008: Snow mould fungus, Typhula ishikariensis group III from Arctic Norway, can grow at a sub-lethal temperature after freezing stress and during flooding. - Sommerfeltia 31: 125-131.

Hoshino, T., Xiao, N. \& Tkachenko, O.B. 2009: Cold adaptation in the phytopathogenic fungi causing snow moulds. - Mycoscience 50: 26-38.

Hoshino, T., Terami, F., Tkachenko, O.B., Tojo, M. \& Matsumoto N. 2010: Mycelial growth of the snow mould fungus, Sclerotinia borealis improved at low water potentials: an adaptation to frozen environment. - Mycoscience 51: 98-102.

Hoshino, T. \& Matsumoto, N. 2012: Cryophilic fungi to denote fungi in the cryosphere. - Fungal Biology Reviews 26:102-105.

Hoshino, T., Xiao, N., Yajima, Y. \& Tkachenko, O.B. 2013a: Fungi in cryosphere: their adaptations to environments. In: Yumoto, I. (ed) 2013: Cold-adapted microorganisms: 51-68. Caister Academic Press. Norfolk.

Hoshino, T., Xiao, N., Yajima, Y., Kida, K., Tokura, K., Murakami, R., Tojo, M. \& Matsumoto, N. 2013b: Ecological strategies of snow moulds to tolerate freezing stress. In: Imai, R., Yoshida, M. \& Matsumoto, N. (eds) 2013. Plant and Microbe Adaptations to Cold in a Changing World: Proceedings of the Plant and Mi- 
crobe Adaptation to Cold Conference, 2012: 285-292. Springer. New York.

Hsiang, T., Matsumoto, N. \& Millett, S. 1999: Biology and management of Typhula snow moulds of turfgrass. - Plant Disease 83: 788-798.

Kohn, L.M. \& Nagasawa, E. 1984: The genus Scleromitula (Sclerotiniaceae), Episclerotium gen. nov. (Leotiaceae) and allied stipitate-capitate species with reduced ectal excipula. - Transactions of the Mycological Society of Japan 25: 127-148.

Kol, E. 1968: Kryobiologie. Biologie und Limnologie des Schnees und Elises. I. Kryovegetation. (Stuttgart, Germany: E. Schweizerbart'sche Verlagebuchhandlung).

Lester, E. \& Large, E.A. 1958: Surveys of clover rot with incidental observations on eel worm in clover: England and Wales 1953-55. - Plant Pathology 7: 115-124.

Lijia, A., Poteri, M., Petäistö, R.-L., Rikala, R., Kurkela, T. \& Kasanen, R. 2010: Fungal diseases in forest nurseries in Finland. - Silva Fennica 44: 525-545.

Matsumoto, N. 1989: Autecology of the pathogenic species of Typhula. - Research Bulletin of Hokkaido National Agriculture Experimental Station 152: 91-162.

Matsumoto, N. 1992: Evolutionary ecology of the pathogenic species of Typhula. - Transactions of the Mycological Society of Japan 33: 269-285.

Matsumoto, N. 1994: Ecological adaptations of low temperature plant pathogenic fungi to diverse winter climates. - Canadian Journal of Plant Pathology 16: 237-240.

Matsumoto, N. 1997: Evolution and adaptation in snow mould fungi. Soil and Microorganisms 50: 13-19. [in Japanese]

Matsumoto, N., \& Tajimi, A. 1988: Life-history strategy in Typhula incarnata and T. ishikariensis biotypes A, $\mathrm{B}$, and $\mathrm{C}$ as determined by sclerotium production. Can. J. Bot. 66:2485-2590.

Matsumoto, N. \& Tronsmo, A.M. 1995: Population structure of Typhula ishikariensis in meadows and pastures in Norway. - Acta Agriculturæ Scandinavica, Section B - Soil \& Plant Science 45: 197-201.

Matsumoto, N., Tronsmo, A.M. \& Shimanuki, T. 1996: Genetic and biological characterisitcs of Typhula ishikariensis isolates from Norway. - European Journal of Plant Pathology 102: 431-439.

Matsumoto, N. \& Hoshino, T. 2008: Fungi in snow environments: psychrophilic moulds. A group of pathogens affecting plants under snow. In: Misra, J.K. \& Deshmukh, S.K. (eds) 2008: Fungi from different environments: 167-186. Science Publisher. Enfield.

Morita, R.Y. 1966: Marine psychrophilic bacteria. Oceanography and Marine Biology: an Annual Review 4: 105-121.

Morita, R.Y. 1975: Psychrophilic Bacteria. - Bacteriology Reviews 39: 144-167.

Moser, M. 2004: Subalpine conifer forests in the Alps, the Altai, and the Rocky Mountains: a comparison of their fungal populations. In: Cripps, C. (ed) 2004: Fungi in Forest Ecosystems: Systematics, Diversity and Ecology: 151-158. New York Botanical Garden Press. Bronx.

Namikawa, Y., Watanabe, T., Saito, I., Takasawa, T. 2004: Growth of the psychrophilic snow mould Sclerotinia borealis on the agar under xerophilic conditions. - Re- search Bulletin of Obihiro University 25: 23-26. [in Japanese with English abstract]

Nedbalová, L., Kociánová, M. \& Lukavský, J. 2008: Ecology of snow algae in the Giant Mts. - Opera Corcontica 45: 59-68.

Nissinen, O. 1996: Analyses of climatic factors affecting snow mould injury in first-year timothy (Phleum pratense L.) with special reference to Sclerotinia borealis. - Acta Universitatis Ouluensis A 289: 1-115.

Ozerskaya, S., Kochkina, G., Ivanushkina, N. \& Gilichinsky, D.A. 2009: Fungi in Permafrost. In: Margesin, R. (ed.) 2009: Permafrost Soils, Soil Biology 16: 85-95. Springer-Verlag. Berlin.

Petäistö, R.-L. \& Laine, A. 1999: Effects of winter storage temperature and age of Scots pine seedlings on the occurrence of disease induced by Gremmeniella abietina. Scandinavian Journal of Forest Research 14: 277-233.

Röed, H. 1960: Sclerotinia borealis Bub. \& Vleg., a cause of winter injuries to winter cereals and grasses in Norway. - Acta Agriculturæ Scandinavica 10: 74-82

Rostrup, E. 1888: Fungi Groenlandiae. - Meddelelser om Grønland 3: 517-590.

Saito, I. 1997: Sclerotinia nivalis, sp. nov., the pathogen of snow mould of herbaceous dicots in northern Japan. - Mycoscience 38: 227-236.

Saito, I. 2001: Snow mould fungi in Sclerotiniaceae. In: Iriki, N., Gaudet, D.A., Tronsmo, A.M., Matsumoto, N., Yoshida, M., Nishimune, A. (eds) 2001: Low Temperature Plant Microbe Interaction Under Snow: 37-48. Hokkaido National Agricultural Experimental Station. Sapporo.

Sakai, A. 1995: Plant distribution and environmental adaptation. Asakura Publishing Co. Tokyo. 164 pp. [in Japanese]

Smith, A. H. 1975: A Field Guide to Western Mushrooms. The University of Michigan Press. Ann Arbor. 288 pp.

Smith, J.D. 1989: Low-temperature fungal disease of amenity turf grasses. In: Simith, J.D., Jackson, N. \& Woolhouse A.R. (eds) 1989: Fungal Disease of Amenity Turf Grasses: 57-114. E \& F Spon. New York.

Stakhov, V.L., Gubin, S.V., Maksimovich, S.V., Rebrikov, D.V., Savilova, A.M., Kochkina, G.A., Ozerskaya, S.M., Ivanushkina, N.E. \& Vorobyva, E.A. 2008: Microbial communities of ancient seeds derived from permanently frozen Pleistocene deposits. - Mikrobiologia 77 : 348-355.

Taylor, T. N., Galtier, J. \& Axsmith, B. J. 1994: Fungi from the Lower Carboniferous of central France. Review of Palaeobotany and Palynology 83: 253-260.

Tomiyama, K. 1955. Studies of the snow blight disease of winter cereals. - Hokkaido National Agriculture Experimental Station Report 47:1-234. [in Japanese, English abstract]

Wolf, F.A. \& Wolf, F.T. 1947: The Fungi Volume II. John Wiley \& Sons, Inc. New York. 353 pp.

Woodbridge, B., Coley-Smith, J.R. \& Reid, D.A. 1989: A new species of Cylindrobasidium parasitic on sclerotia of Typhula incaranata. - Transactions of British Mycological Society 91: 166-169.

Yokota, S., Uozumi, T. \& Matsuzaki, S. 1974: Scleroderris canker of Todo-fir in Hokkaido, northern Japan II. Physiological and pathological characteristics of the causal fungus. - European Journal of Forest Pathology 4: 155-166. 